\title{
Does Gender Have an Effect on Craniofacial Measurements?
}

\author{
Lale Taner (D), Gamze Metin Gürsoy (D), Fatma Deniz Uzuner (D)
}

Department of Orthodontics, Gazi University School of Dentistry, Ankara, Turkey

Cite this article as: Taner L, Metin Gürsoy G, Uzuner FD. Does Gender Have an Effect on Craniofacial Measurements? Turk J Orthod 2019; 32(2): 59-64.

\section{ABSTRACT}

Objective: The aim of this cross-sectional study was to evaluate craniofacial structures in terms of different sagittal relations and gender in adolescent individuals.

Methods: Pre-treatment dental models, lateral cephalometric, and hand-wrist radiographs of 223 adolescent subjects (102 male, 121 female) were evaluated. Subjects were divided into the Angle Class I, II, and III (skeletally) subgroups according to the ANB angle. Four angular and 33 linear measurements were used to evaluate the lateral cephalometric radiographs relative to the R1 and R2 coordinate system. The Kolmogorov-Smirnov test was performed to assess the normal distribution of the data. The independent samples $t$-test and Mann-Whitney $\mathrm{U}$ test were used for the comparison of male and female subjects in each group. The values were considered statistically significant at $\mathrm{p}<0.05$.

Results: The vertical facial dimension was found to be significantly greater in Class I male subjects than in female subjects (SGo, $p=0.023$; ANS-M, $p=0.036$ ), and there was a protrusive maxilla ( $R 2 A N S, p=0.038 ; R 2 A, p=0.016$ ), while the mandibular sagittal position and the mandibular dimension were similar. The maxilla was placed protrusively (R2ANS, $p=0.001 ; R 2 A, p=0.002$ ), while the mandible was found to be larger both in the position and dimension ( $\mathrm{CoGn}, \mathrm{p}=0.003 ; \mathrm{R} 2 \mathrm{M}, \mathrm{p}=0.014$ ) in Class II male subjects. Class III male and female subjects were found to have similar maxillary and mandibular vertical and sagittal location and dimensions.

Conclusion: Class I and II subjects showed more gender variation than Class III subjects. The gender-related results of this study declare that treatment planning of malocclusions should be based on gender differences rather than general treatment procedures, which will be useful in achieving successful orthodontic treatment results.

Keywords: Cephalometrics, Class I, Class II, Class III, craniofacial, gender, orthodontics

\section{INTRODUCTION}

An accurate diagnosis of malocclusion and related treatment planning are the key of a successful orthodontic treatment. The purpose of orthodontic treatment is to provide acceptable occlusion and function, as well as aesthetics. Subjects with dental and/or skeletal malocclusions may have greater restrictions in terms of the quality of life, discomfort, and social and functional limitations. A detailed identification of hard and soft tissue problems by advancing technology facilitates reaching of the best results for the orthodontist. When the studies evaluating the craniofacial characteristics related to malocclusion are examined, it is observed that the results vary widely (1-4). One of the most important reasons for the variety is the race of samples included in the studies. In addition, the sample of age and gender, the sample size, and methodology differences may be responsible for the divergent outcomes. While the prevalence of malocclusion varies from country to country and among different age and gender groups, the most common malocclusion type in the population has been reported as Angle Class I malocclusions. Class II and Class III malocclusions are the less frequently observed malocclusion types (5-7). The need for orthodontic treatment or a type of malocclusion was noted to be similar between the genders. Gender-related craniofacial differences have been mentioned in the literature, while there is insufficient knowledge about gender variations between the malocclusion types (8-10). 
This study was planned to provide additional information to verify more realistically the possible association between malocclusion and craniofacial morphology. The purpose of the present study was to compare the craniofacial structures in Class I, II, and III Turkish male and female subjects using cephalometric films, and to evaluate the relation of gender in craniofacial morphologic structures.

\section{METHODS}

This retrospective study was approved by the Ethical Committee of Gazi University (02.12.2016/14). A total of 2700 patients' pre-treatment lateral cephalograms, hand-wrist radiographs, dental models, and clinical reports were collected from the archives of the Orthodontics Department of the Gazi University. First, subjects who were not in the adolescent period were excluded. Subjects with the skeletal age 10-11.5 years were selected. Later, subjects with no previous loss of primary molars, no history of previous orthodontic or prosthodontic treatment, serial extraction, without acquired or congenitally missing teeth, having no stainless steel crowns or large restorations, facial and/ or dental trauma, and no craniofacial anomalies were selected. In addition, subjects without the optimal range of the SNGoGn angle $\left(32 \pm 6^{\circ}\right)$ were excluded. Also, all subjects were Caucasian Turkish to avoid ethnic differences in the craniofacial morphology. Finally, the sample consisted of 223 subjects (102 male, 121 female) ranging in the skeletal age between 10 and 11.5 years.

There were three groups constructed and matched according to the ANB angle value:

- Group 1 ( $n=93$ ): 50 female and 43 male subjects with the skeletal Class $1\left(0<\right.$ ANB angle $\left.\leq 4^{\circ}\right)$ relationship.

- Group 2 ( $n=90): 51$ female and 39 male subjects with the skeletal Class $2\left(\mathrm{ANB}>4^{\circ}\right)$ relationship.

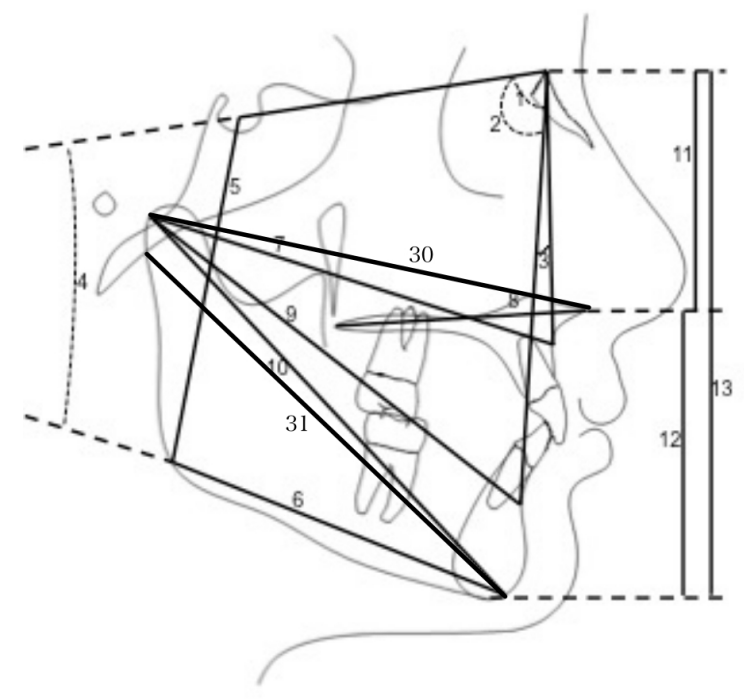

- Group 3 ( $n=40): 20$ female and 20 male subjects with the skeletal Class $3\left(\mathrm{ANB} \leq 0^{\circ}\right)$ relationship.

Hand-wrist radiographs were assessed according to the method of Greulich and Pyle (11), and the skeletal age was calculated.

Four angular and 33 linear measurements were used to evaluate the lateral cephalometric radiographs taken under standardized conditions. The landmarks, reference lines, and measurements are shown in Figure 1.

The measurements were made relative to the $R_{1}$ and $R_{2}$ coordinate system. $R_{1}$ was constructed $7^{\circ}$ to the $S N$ plane, and $R_{2}$ was constructed perpendicular to $\mathrm{R}_{1}$ at the Sella, and measurements were made according to a previous study (12). Following measurements based on the selected points were obtained from the cephalometric radiographs.

Linear measurements: CoA, ANS-PNS, CoB, CoGn, CoANS, SGo, GoGn, ArGn, N-ANS, ANS-M, N-M, R ANS, R PNS, R, M, R, A, R B, $R_{1} P g, R_{1} G n, R_{1}$ Co, R Ar, R Go, R ANT, R ANS, R PNS, R $M, R_{2} A, R_{2} B$, $R_{2} P g, R_{2} G n, R_{2} C o, R_{2} A r, R_{2} G o, R_{2} A N T$

Angular measurements: SNA, SNB, ANB, SNGoGn

Each cephalometric radiograph was traced, and all parameters were measured by the same investigator. To estimate the method error, 75 randomly selected lateral cephalometric radiographs were retraced and re-measured 2 weeks later by the same examiner.

\section{Statistical Analysis}

The method error was assessed with the intraclass correlation coefficient (ICC). The ICC for all measured parameters showed a high reliability and reproducibility of measurements ( $r>0.95)$ (Table 1). 
Table 1. Intra-examiner reproducibility for some parameters

\begin{tabular}{|llcccccc|}
\hline Groups & SNA & SN-GoGn & CoPNS & R1Ar & R1Go & R2ANS \\
\hline Class 1 (n: 30) & 0.997 & 0.998 & 0.953 & 0.988 & 0.995 & 0.988 \\
Class 2 (n: 30) & 0.995 & 0.999 & 0.974 & 0.995 & 0.993 & 0.965 \\
Class 3 (n: 15) & 0.986 & 0.995 & 0.983 & 0.991 & 0.999 & 0.985 \\
\hline \multicolumn{2}{ll}{ Intraclass correlation coefficient (ICC), r>0.95 } & & & &
\end{tabular}

\begin{tabular}{|c|c|c|c|}
\hline & $\begin{array}{l}\text { Male } \\
(n=43)\end{array}$ & $\begin{array}{c}\text { Female } \\
(n=50)\end{array}$ & $\begin{array}{c}\text { Male-Female } \\
\text { Comparison }\end{array}$ \\
\hline & Mean \pm SD & Mean \pm SD & $\mathbf{p}$ \\
\hline N-ANS (mm) & $52.35 \pm 2.9$ & $51.74 \pm 2.4$ & $\mathrm{NS}^{\dagger}$ \\
\hline ANS-M (mm) & $66.02 \pm 4.6$ & $63.96 \pm 4.6$ & $0.036^{+}$ \\
\hline $\mathrm{N}-\mathrm{M}(\mathrm{mm})$ & $117.77 \pm 5.9$ & $115.22 \pm 5.6$ & $0.037^{\dagger}$ \\
\hline S-Go (mm) & $75.47 \pm 4.9$ & $71.6 \pm 8$ & $0.023^{*}$ \\
\hline SNGoGn $\left({ }^{\circ}\right)$ & $32.35 \pm 3.4$ & $32.64 \pm 3.1$ & $\mathrm{NS}^{+}$ \\
\hline ANB $\left({ }^{\circ}\right)$ & $2.1 \pm 1.2$ & $2.21 \pm 1.1$ & $\mathrm{NS}^{*}$ \\
\hline SNA $\left({ }^{\circ}\right)$ & $79.67 \pm 3.4$ & $79.64 \pm 3.6$ & $\mathrm{NS}^{+}$ \\
\hline ANS-PNS (mm) & $53.31 \pm 3.2$ & $52.23 \pm 2.7$ & $\mathrm{NS}^{+}$ \\
\hline CoANS (mm) & $90.88 \pm 4.4$ & $89.56 \pm 4.8$ & NS* \\
\hline $\mathrm{CoA}(\mathrm{mm})$ & $86.97 \pm 4.4$ & $85.5 \pm 4.6$ & $\mathrm{NS}^{+}$ \\
\hline $\mathrm{R}_{1} \mathrm{ANS}(\mathrm{mm})$ & $43.97 \pm 2.9$ & $44.47 \pm 4.2$ & $\mathrm{NS}^{*}$ \\
\hline $\mathrm{R}_{1} \mathrm{~A}(\mathrm{~mm})$ & $49.69 \pm 2.9$ & $49.59 \pm 3.5$ & $N S^{*}$ \\
\hline $\mathrm{R}_{1} \mathrm{PNS}(\mathrm{mm})$ & $43.87 \pm 2.7$ & $42.21 \pm 4.8$ & $0.030^{*}$ \\
\hline $\mathrm{R}_{2} \mathrm{PNS}(\mathrm{mm})$ & $20.64 \pm 3.2$ & $19.44 \pm 3.1$ & $\mathrm{NS}^{+}$ \\
\hline $\mathrm{R}_{2} \mathrm{ANS}(\mathrm{mm})$ & $73.51 \pm 4.4$ & $71.66 \pm 4$ & $0.038^{+}$ \\
\hline $\mathrm{R}_{2} \mathrm{~A}(\mathrm{~mm})$ & $67.83 \pm 4.4$ & $65.62 \pm 4.1$ & $0.016^{+}$ \\
\hline
\end{tabular}

Descriptive statistics of the craniofacial measurements in Class I, Class II, and Class III female and male samples were calculated as the mean and standard deviation. The Kolmogorov-Smirnov test was performed to assess the normal distribution of the data in the sample. The independent samples t-test was used for normal distribution and the Mann-Whitney $U$ Test for non-normal distribution to compare male and female subjects in the groups. The values were considered statistically significant at $p<0.05$.

\section{RESULTS}

Comparison of Class I female and male subjects. There was no difference in the SNGoGn angle between females and males in the Class 1 group. However, the vertical anterior and posterior facial heights were longer in male than in female subjects. Vertical maxillary variables were similar except R1PNS, which was larger in male subjects (Table 2).

Maxillary measurements $\left(R_{2} A N S, R_{2} A\right)$ were significantly greater in male subjects than females (Table 2).

Mandibular vertical measurements $\left(R_{1} G n, R_{1} P g, R_{1} A N T, R_{1} M\right)$ were found significantly higher in male subjects than in female subjects. Also, CoB was found to be longer in males (Table 3 ).

\begin{tabular}{|c|c|c|c|}
\hline & $\begin{array}{c}\text { Male } \\
(n=43)\end{array}$ & $\begin{array}{c}\text { Female } \\
(n=50)\end{array}$ & $\begin{array}{c}\text { Male-Female } \\
\text { Comparison }\end{array}$ \\
\hline & Mean \pm SD & Mean \pm SD & $\mathbf{p}$ \\
\hline SNB $\left(^{\circ}\right)$ & $77.5 \pm 3.3$ & $77.4 \pm 3.8$ & $\mathrm{NS}^{+}$ \\
\hline $\operatorname{CoB}(\mathrm{mm})$ & $102.19 \pm 5.2$ & $99.4 \pm 5.3$ & $0.013^{+}$ \\
\hline $\operatorname{ArGn}(\mathrm{mm})$ & $106.35 \pm 5.8$ & $104 \pm 5.6$ & $\mathrm{NS}^{*}$ \\
\hline CoGn (mm) & $111.53 \pm 6.9$ & $109.54 \pm 5.1$ & $N S^{*}$ \\
\hline GoGn (mm) & $73.5 \pm 3.7$ & $72.46 \pm 4$ & $N S^{*}$ \\
\hline $\mathrm{R}_{1} \mathrm{Co}(\mathrm{mm})$ & $21.79 \pm 3$ & $20.69 \pm 2.6$ & $\mathrm{NS}^{+}$ \\
\hline $\mathrm{R}_{1} \operatorname{Ar}(\mathrm{mm})$ & $31.45 \pm 2.9$ & $30.56 \pm 3$ & $\mathrm{NS}^{+}$ \\
\hline $\mathrm{R}_{1} \mathrm{Go}(\mathrm{mm})$ & $74.85 \pm 4.6$ & $73.02 \pm 4.5$ & $N S^{*}$ \\
\hline $\mathrm{R}_{1} \mathrm{ANT}(\mathrm{mm})$ & $85.29 \pm 5.1$ & $83.13 \pm 4.4$ & $0.034^{+}$ \\
\hline $\mathrm{R}_{1} \mathrm{~B}(\mathrm{~mm})$ & $89.58 \pm 5.4$ & $87.45 \pm 5.3$ & $\mathrm{NS}^{+}$ \\
\hline $\mathrm{R}_{1} \mathrm{Pg}(\mathrm{mm})$ & $102.4 \pm 5.8$ & $99.52 \pm 5.1$ & $0.013^{+}$ \\
\hline $\mathrm{R}_{1} \mathrm{Gn}(\mathrm{mm})$ & $106.6 \pm 6$ & $104.1 \pm 5.2$ & $0.035^{\dagger}$ \\
\hline $\mathrm{R}_{1} \mathrm{M}(\mathrm{mm})$ & $107.86 \pm 5.8$ & $105.24 \pm 5.2$ & $0.025^{\dagger}$ \\
\hline $\mathrm{R}^{2} \mathrm{Co}(\mathrm{mm})$ & $14.6 \pm 3$ & $14.67 \pm 3.1$ & $N S^{*}$ \\
\hline $\mathrm{R}^{2} \mathrm{Ar}(\mathrm{mm})$ & $15.62 \pm 3.3$ & $16.22 \pm 3.1$ & $\mathrm{NS}^{*}$ \\
\hline $\mathrm{R}^{2} \mathrm{Go}(\mathrm{mm})$ & $6.84 \pm 4.7$ & $8.24 \pm 4.6$ & $\mathrm{NS}^{+}$ \\
\hline $\mathrm{R}^{2} \mathrm{ANT}(\mathrm{mm})$ & $12.33 \pm 5.1$ & $11.71 \pm 5$ & $\mathrm{NS}^{+}$ \\
\hline $\mathrm{R}^{2} \mathrm{~B}(\mathrm{~mm})$ & $61.9 \pm 6.2$ & $59.6 \pm 6$ & $\mathrm{NS}^{+}$ \\
\hline $\mathrm{R}^{2} \mathrm{Pg}(\mathrm{mm})$ & $62.2 \pm 6.8$ & $59.9 \pm 6.4$ & $\mathrm{NS}^{+}$ \\
\hline $\mathrm{R}^{2} \mathrm{Gn}(\mathrm{mm})$ & $59.88 \pm 7.1$ & $57.16 \pm 6.7$ & $\mathrm{NS}^{+}$ \\
\hline $\mathrm{R}^{2} \mathrm{M}(\mathrm{mm})$ & $55.65 \pm 7.4$ & $52.84 \pm 6.7$ & $\mathrm{NS}^{+}$ \\
\hline
\end{tabular}

Comparison of Class II female and male subjects. There was no difference in the SNGoGn angle between females and males in the Class II group. However, a lower facial height and posterior facial height were longer in male than in female subjects. Maxillary variables $R_{2} A N S, R_{2} A$, CoANS, and CoA were found to be significantly larger in male subjects than in female (Table 4).

There were significant differences in the mandibular vertical $\left(R_{1} G n, R_{1} B, R_{1} P g, R_{1} A r, R_{1} G o, R_{1} A N T, R_{1} M\right)$, sagittal $\left(R_{2} M, R_{2} P g, R_{2} G n\right.$, $R_{2} B, R_{2} A N T$ ), and dimension measurements (ArGn, CoB, CoGn, GoGn) between female and male subjects, and they were greater in males (Table 5).

Comparison of Class III female and male subjects. There were no significant differences between male and female subjects for sagittal and vertical variables except $R_{2} P N S$ and $R_{2} A N T$, which were larger in males (Tables 6, 7). 
Table 4. Gender comparison of maxillary and vertical variables in Class II subjects

\begin{tabular}{|c|c|c|c|}
\hline & $\begin{array}{l}\text { Male } \\
(n=39)\end{array}$ & $\begin{array}{l}\text { Female } \\
(n=51)\end{array}$ & $\begin{array}{c}\text { Male-Female } \\
\text { Comparison }\end{array}$ \\
\hline & Mean $\pm S D$ & Mean \pm SD & $\mathbf{p}$ \\
\hline N-ANS (mm) & $52.96 \pm 3.3$ & $51.82 \pm 3.7$ & $0.002^{+}$ \\
\hline ANS-M (mm) & $66.74 \pm 4.4$ & $64.04 \pm 3.5$ & $0.001^{\dagger}$ \\
\hline $\mathrm{N}-\mathrm{M}(\mathrm{mm})$ & $118.82 \pm 5.2$ & $114.96 \pm 5$ & $\mathrm{NS}^{+}$ \\
\hline S-Go (mm) & $75.51 \pm 5$ & $72.18 \pm 7.6$ & $0.012^{*}$ \\
\hline SNGoGn $\left({ }^{\circ}\right)$ & $33.26 \pm 3.3$ & $33.56 \pm 2.8$ & $\mathrm{NS}^{*}$ \\
\hline ANB $\left(^{\circ}\right)$ & $6.12 \pm 1.3$ & $5.91 \pm 1.2$ & $\mathrm{NS}^{*}$ \\
\hline SNA $\left(^{\circ}\right)$ & $81.69 \pm 3.4$ & $80.81 \pm 3$ & $\mathrm{NS}^{+}$ \\
\hline ANS-PNS (mm) & $54.53 \pm 3$ & $53.38 \pm 3.3$ & $\mathrm{NS}^{+}$ \\
\hline CoANS (mm) & $94.44 \pm 4.1$ & $91.31 \pm 4.4$ & $0.001^{+}$ \\
\hline $\mathrm{CoA}(\mathrm{mm})$ & $90.72 \pm 3.6$ & $87.83 \pm 4.5$ & $0.005^{*}$ \\
\hline $\mathrm{R}_{1} \mathrm{ANS}(\mathrm{mm})$ & $44.38 \pm 3.2$ & $44.59 \pm 3$ & $N S^{*}$ \\
\hline $\mathrm{R}_{1} \mathrm{~A}(\mathrm{~mm})$ & $50 \pm 4.2$ & $49.98 \pm 3.6$ & $\mathrm{NS}^{*}$ \\
\hline $\mathrm{R}_{1} \mathrm{PNS}$ (mm) & $43.79 \pm 2.8$ & $42.56 \pm 2.7$ & $\mathrm{NS}^{*}$ \\
\hline $\mathrm{R}_{2} \mathrm{PNS}(\mathrm{mm})$ & $21.31 \pm 3.9$ & $19.78 \pm 2.4$ & $\mathrm{NS}^{*}$ \\
\hline $\mathrm{R}_{2} \mathrm{ANS}$ (mm) & $75.41 \pm 3.9$ & $72.82 \pm 3.4$ & $0.001^{\dagger}$ \\
\hline $\mathrm{R}_{2} \mathrm{~A}(\mathrm{~mm})$ & $69.86 \pm 4.4$ & $67.1 \pm 3.6$ & $0.002^{\dagger}$ \\
\hline
\end{tabular}

Table 5. Gender comparison of mandibular variables in Class II subjects

\begin{tabular}{|c|c|c|c|}
\hline & $\begin{array}{l}\text { Male } \\
(n=39)\end{array}$ & $\begin{array}{c}\text { Female } \\
(n=51)\end{array}$ & $\begin{array}{c}\text { Male-Female } \\
\text { Comparison }\end{array}$ \\
\hline & Mean \pm SD & Mean \pm SD & $\mathbf{p}$ \\
\hline $\operatorname{SNB}\left({ }^{\circ}\right)$ & $75.57 \pm 3$ & $74.9 \pm 2.5$ & $\mathrm{NS}^{+}$ \\
\hline $\mathrm{CoB}(\mathrm{mm})$ & $101.21 \pm 4.8$ & $97.78 \pm 4.1$ & $0.001^{+}$ \\
\hline $\operatorname{ArGn}(\mathrm{mm})$ & $103.49 \pm 11.6$ & $101.41 \pm 4.1$ & $0.004^{*}$ \\
\hline CoGn (mm) & $111.54 \pm 5.1$ & $108.33 \pm 4.8$ & $0.003^{+}$ \\
\hline GoGn (mm) & $73.18 \pm 3.9$ & $70.69 \pm 4.4$ & $0.007^{+}$ \\
\hline $\mathrm{R}_{1} \mathrm{Co}(\mathrm{mm})$ & $20.24 \pm 3.1$ & $19.07 \pm 2.6$ & $\mathrm{NS}^{+}$ \\
\hline $\mathrm{R}_{1} \operatorname{Ar}(\mathrm{mm})$ & $31.36 \pm 3$ & $29.68 \pm 2.8$ & $0.008^{+}$ \\
\hline $\mathrm{R}_{1} \mathrm{Go}(\mathrm{mm})$ & $74.47 \pm 4.8$ & $72.39 \pm 3.8$ & $0.009^{*}$ \\
\hline $\mathrm{R}_{1} \mathrm{ANT}(\mathrm{mm})$ & $85.58 \pm 4.5$ & $82.9 \pm 4.3$ & $0.002^{*}$ \\
\hline $\mathrm{R}_{1} \mathrm{~B}(\mathrm{~mm})$ & $89.05 \pm 5$ & $85.95 \pm 4.1$ & $0.002^{\dagger}$ \\
\hline $\mathrm{R}_{1} \mathrm{Pg}(\mathrm{mm})$ & $102.72 \pm 5.2$ & $99.42 \pm 5.1$ & $0.003^{+}$ \\
\hline $\mathrm{R}_{1} \mathrm{Gn}(\mathrm{mm})$ & $106.64 \pm 5.3$ & $103.1 \pm 4.7$ & $0.002^{\dagger}$ \\
\hline $\mathrm{R}_{1} \mathrm{M}(\mathrm{mm})$ & $107.67 \pm 5.3$ & $104.48 \pm 4.8$ & $0.003^{*}$ \\
\hline $\mathrm{R}_{2} \mathrm{Co}(\mathrm{mm})$ & $15.91 \pm 3.3$ & $15.09 \pm 3$ & $\mathrm{NS}^{+}$ \\
\hline $\mathrm{R}_{2} \operatorname{Ar}(\mathrm{mm})$ & $16.97 \pm 3.3$ & $16.8 \pm 3.1$ & $\mathrm{NS}^{+}$ \\
\hline $\mathrm{R}_{2} \mathrm{Go}(\mathrm{mm})$ & $9.72 \pm 4.6$ & $10.26 \pm 4.4$ & $\mathrm{NS}^{\dagger}$ \\
\hline $\mathrm{R}_{2} \mathrm{ANT}(\mathrm{mm})$ & $10.56 \pm 5.3$ & $8.23 \pm 4.8$ & $0.032^{\dagger}$ \\
\hline $\mathrm{R}_{2} \mathrm{~B}(\mathrm{~mm})$ & $58.64 \pm 5.8$ & $56.12 \pm 4.2$ & $0.021^{\dagger}$ \\
\hline $\mathrm{R}_{2} \mathrm{Pg}(\mathrm{mm})$ & $58.52 \pm 6.5$ & $56.15 \pm 4.6$ & $0.048^{+}$ \\
\hline $\mathrm{R}_{2} \mathrm{Gn}(\mathrm{mm})$ & $56.06 \pm 6.6$ & $53.41 \pm 4.8$ & $0.03^{+}$ \\
\hline $\mathrm{R}_{2} \mathrm{M}(\mathrm{mm})$ & $52.08 \pm 7$ & $48.65 \pm 5.9$ & $0.014^{+}$ \\
\hline
\end{tabular}

Table 6. Gender comparison of maxillary and vertical variables in Class III subjects

\begin{tabular}{|c|c|c|c|}
\hline & $\begin{array}{c}\text { Male } \\
(n=20)\end{array}$ & $\begin{array}{c}\text { Female } \\
(n=20)\end{array}$ & $\begin{array}{c}\text { Male-Female } \\
\text { Comparison }\end{array}$ \\
\hline & Mean \pm SD & Mean $\pm S D$ & $\mathbf{p}$ \\
\hline N-ANS (mm) & $52.35 \pm 3.6$ & $51.45 \pm 4.1$ & $\mathrm{NS}^{+}$ \\
\hline ANS-M (mm) & $65.1 \pm 5.6$ & $62.72 \pm 5.9$ & NS* \\
\hline N-M (mm) & $117.45 \pm 7.7$ & $113.68 \pm 6.9$ & $\mathrm{NS}^{+}$ \\
\hline S-Go (mm) & $76.13 \pm 11.8$ & $73.88 \pm 4.4$ & NS* \\
\hline SNGoGn $\left({ }^{\circ}\right)$ & $32.88 \pm 3.3$ & $31.23 \pm 3.1$ & $\mathrm{NS}^{+}$ \\
\hline ANB $\left(^{\circ}\right)$ & $-2.58 \pm 1.6$ & $-1.8 \pm 1.3$ & $\mathrm{NS}^{*}$ \\
\hline SNA $\left(^{\circ}\right)$ & $78.43 \pm 3.6$ & $79.05 \pm 2.8$ & $\mathrm{NS}^{+}$ \\
\hline ANS-PNS (mm) & $51.18 \pm 3.3$ & $51.35 \pm 3.6$ & $\mathrm{NS}^{+}$ \\
\hline CoANS (mm) & $87.3 \pm 6.3$ & $86.2 \pm 6$ & $\mathrm{NS}^{+}$ \\
\hline $\mathrm{CoA}(\mathrm{mm})$ & $82.18 \pm 6.7$ & $81.55 \pm 5.2$ & $\mathrm{NS}^{+}$ \\
\hline $\mathrm{R}_{1}$ ANS (mm) & $44.05 \pm 3.2$ & $43.08 \pm 3.8$ & $\mathrm{NS}^{+}$ \\
\hline $\mathrm{R}_{1} \mathrm{~A}(\mathrm{~mm})$ & $48.53 \pm 4.7$ & $47.1 \pm 4.9$ & $\mathrm{NS}^{+}$ \\
\hline $\mathrm{R}_{1} \mathrm{PNS}(\mathrm{mm})$ & $43.15 \pm 3.5$ & $41.68 \pm 2.7$ & $N S^{*}$ \\
\hline $\mathrm{R}_{2} \mathrm{PNS}(\mathrm{mm})$ & $19.65 \pm 2.1$ & $18 \pm 2.1$ & $0.018^{+}$ \\
\hline $\mathrm{R}_{2}$ ANS (mm) & $70.5 \pm 4.6$ & $68.9 \pm 4.5$ & $\mathrm{NS}^{+}$ \\
\hline $\mathrm{R}_{2} \mathrm{~A}(\mathrm{~mm})$ & $63.65 \pm 3.5$ & $62.43 \pm 4.2$ & $\mathrm{NS}^{+}$ \\
\hline
\end{tabular}

Table 7. Gender comparison of mandibular variables in Class III subjects

\begin{tabular}{|c|c|c|c|}
\hline & $\begin{array}{c}\text { Male } \\
(n=20)\end{array}$ & $\begin{array}{c}\text { Female } \\
(n=20)\end{array}$ & $\begin{array}{c}\text { Male-Female } \\
\text { Comparison }\end{array}$ \\
\hline & Mean \pm SD & Mean \pm SD & $\mathbf{p}$ \\
\hline SNB $\left(^{\circ}\right)$ & $81.02 \pm 3$ & $80.65 \pm 2.9$ & $\mathrm{NS}^{+}$ \\
\hline $\mathrm{CoB}(\mathrm{mm})$ & $105.43 \pm 5.4$ & $101.88 \pm 6.7$ & $\mathrm{NS}^{+}$ \\
\hline $\operatorname{ArGn}(\mathrm{mm})$ & $109 \pm 6.7$ & $106.6 \pm 6.8$ & $\mathrm{NS}^{+}$ \\
\hline CoGn (mm) & $111.5 \pm 13.3$ & $111.55 \pm 10.4$ & $\mathrm{NS}^{*}$ \\
\hline GoGn (mm) & $69.2 \pm 11.9$ & $73.3 \pm 3.6$ & $\mathrm{NS}^{*}$ \\
\hline $\mathrm{R}_{1} \mathrm{Co}(\mathrm{mm})$ & $20.65 \pm 3.6$ & $20.2 \pm 3.1$ & $N S^{*}$ \\
\hline $\mathrm{R}_{1} \operatorname{Ar}(\mathrm{mm})$ & $30.65 \pm 3.3$ & $30.25 \pm 3.5$ & $\mathrm{NS}^{+}$ \\
\hline $\mathrm{R}_{1} \mathrm{Go}(\mathrm{mm})$ & $77.2 \pm 8.3$ & $73.4 \pm 4.3$ & $\mathrm{NS}^{*}$ \\
\hline $\mathrm{R}_{1} \mathrm{ANT}(\mathrm{mm})$ & $84.5 \pm 6.1$ & $82.37 \pm 4.3$ & $\mathrm{NS}^{*}$ \\
\hline $\mathrm{R}_{1} \mathrm{~B}(\mathrm{~mm})$ & $90 \pm 6.1$ & $86.45 \pm 6$ & $\mathrm{NS}^{+}$ \\
\hline $\mathrm{R}_{1} \mathrm{Gn}(\mathrm{mm})$ & $107 \pm 7.3$ & $102.6 \pm 6.8$ & $\mathrm{NS}^{*}$ \\
\hline $\mathrm{R}_{1} \mathrm{Pg}(\mathrm{mm})$ & $101.35 \pm 7.3$ & $97.28 \pm 7$ & $\mathrm{NS}^{*}$ \\
\hline $\mathrm{R}_{1} \mathrm{M}(\mathrm{mm})$ & $107.95 \pm 7.4$ & $103.98 \pm 6.6$ & $\mathrm{NS}^{*}$ \\
\hline $\mathrm{R}_{2} \mathrm{Co}(\mathrm{mm})$ & $14.05 \pm 2.8$ & $14.05 \pm 2.9$ & $\mathrm{NS}^{+}$ \\
\hline $\mathrm{R}_{2} \operatorname{Ar}(\mathrm{mm})$ & $15 \pm 3.1$ & $15.3 \pm 3.4$ & $\mathrm{NS}^{+}$ \\
\hline $\mathrm{R}_{2} \mathrm{Go}(\mathrm{mm})$ & $3.35 \pm 3.6$ & $5.9 \pm 4.8$ & $\mathrm{NS}^{+}$ \\
\hline $\mathrm{R}_{2} \mathrm{ANT}(\mathrm{mm})$ & $15 \pm 3.8$ & $12.4 \pm 3.7$ & $0.035^{\dagger}$ \\
\hline $\mathrm{R}_{2} \mathrm{~B}(\mathrm{~mm})$ & $65.15 \pm 4.3$ & $63.05 \pm 6.2$ & $N S^{*}$ \\
\hline $\mathrm{R}_{2} \mathrm{Pg}(\mathrm{mm})$ & $65.7 \pm 4.2$ & $64.15 \pm 6.3$ & $N S^{*}$ \\
\hline $\mathrm{R}_{2} \mathrm{Gn}(\mathrm{mm})$ & $63.15 \pm 4.2$ & $61.53 \pm 6.3$ & $\mathrm{NS}^{*}$ \\
\hline $\mathrm{R}_{2} \mathrm{M}(\mathrm{mm})$ & $58.5 \pm 4.4$ & $56.9 \pm 6.1$ & $\mathrm{NS}^{*}$ \\
\hline
\end{tabular}




\section{DISCUSSION}

The differential diagnosis of the skeletal pattern and the dental classification of malocclusion are important factors in planning the orthodontic treatment. The diagnosis of possible consequences in an early phase of the skeletal problem can help to prevent the development of more difficult orthodontic problems via target-related therapies. The upper and lower jaws that serve as the base for the teeth should be in the correct position, relative to each other and to the cranial base. In the light of this knowledge, we planned this study to provide and compare data for gender and malocclusion relations and for early prediction of need-oriented treatment. To obtain detailed information, we chose to make the measurements according to a coordinate system and at a specific growing stage. In view of the results of this study, malocclusions may be distinguished at an early stage in relation with gender variations providing possible pre-treatment outcome, which can reduce dental problems and shorten and/ or facilitate the orthodontic treatment, especially for Class III patients.

Although there are many studies related to malocclusion types according to ethnic groups, previous reports of gender variations in relation to malocclusion prevalence are inconclusive (3$5,9,13)$.

All subjects in this study had similar optimal vertical growth patterns. This is an important factor to distinguish in order to eliminate possible effects of the vertical growth pattern on the measurements.

Comparison of Class I female and male subjects. In a previous study to determine the craniofacial norms in Anatolian Turkish adults with Class I malocclusion, in line with the findings of our study, researchers found minimal differences between males and females. The maxilla and mandible were located anteriorly regarding the condyle, and lower and upper face heights were longer in males compared to female subjects (14). However, the mean values of the variables were higher than the means of the presented study due to the different development stages of the subjects. Maxilla was found to be more protrusive in males than females whereas the sagittal position of the mandible was similar between the genders in this study. Mandibular length and vertical mandibular measurements were higher in males, and posterior portion of the maxilla (PNS) was located more downward. The results of another study in the same developmental stage, supported some of our outcomes, and the maxillary and mandibular length was found significantly larger in male than female subjects (15). In support, other researchers noted that Turkish adult male patients show larger vertical and sagittal skeletal values than the female patients (16).

Comparison of Class II female and male subjects. Previous studies showed that gender variation had little or no effect on skeletal and dental components of Class II malocclusion (17-20). However, in this present study, many differences were found between male and female subjects for vertical, mandibular, and maxillary variables. Anterior and posterior facial heights were significantly larger in male subjects, although the SNGoGn angle was similar between male and females. Also, the maxilla was located more anteriorly in male subjects, and the maxillary length was larger compared to the female subjects in the present study. In line with our study findings, researchers noted that Chinese males had an anteriorly long face and protruded maxilla compared to females $(18,20)$. In addition, researchers noted that male subjects had a more retruded mandible compared to female subjects. As a result of that, a straight profile was more common in female subjects (18). On the contrary, the mandible was found larger and located more anteriorly compared to female subjects in this present study.

Comparison of Class III female and male subjects. In a previous study, gender differences in Class III malocclusion were found at 9-12 years of age. The most obvious differences were in the vertical position of the lower incisors, the lower lip in relation to the aesthetic plane, and anterior cranial base dimension (9). Findings in the present study were similar in craniofacial features except the sagittal position of the PNS and ANT points, which were located anteriorly in male subjects. Male and female subjects included in the present study had similar craniofacial features. This result shows that similar treatment procedures may be applied for Class III male and female subjects, but it should not be forgotten that the growth and development in male individuals will be longer and greater when compared to females.

Bacetti et al. (9) explained that the differential outcomes of female and male subjects were due to different development stages at the same chronological age and that gender differences began to become prominent between girls and boys after 12 years. In their study, female subjects were at the age of 13 and had reached a post-pubertal stage in the skeletal development, but the male subjects were still at the pubertal stage.

This reveals the importance of the selection of subjects according to the skeletal age and in similar developmental stages as possible. We limited the range of the skeletal ages of the adolescent subjects in this study to maximize the similar growth potential of the patients. The age of 10-11.5 years is of special importance for beginning functional orthodontic therapies, and the awareness of gender-related craniofacial variations will lead to specific need-oriented treatment plans.

The most spectacular findings in this present study were that the variations between male and female individuals were seen in the same parameters (ANS-M, SGo, R2ANS, R $A, C o B, R_{1} G n, R_{1} P g$, $\left.\mathrm{R}_{1} A N T, R_{1} M\right)$ for skeletal Class I and Class II anomalies. Vertical and sagittal measurements reveal that the gender-related craniofacial growth in subjects with similar vertical growth patterns result in a more protrusive maxilla and downward position of the mandible in skeletal Class I male and II male subjects than female subjects. Although the skeletal classes were different, the female and male craniofacial variations were similar. However, skeletal Class III subjects showed similar characteristics in female and male subjects, unlike Class I and II individuals. Possible reasons may be the smaller sample size of the Class III group as a limitation of this study. 
The prevalence of Class III malocclusion is low in the Turkish population, as well as in other societies, and the fact that both the age interval and the specific vertical ranges were limited, the number of Class III samples is small $(5,7)$.

\section{CONCLUSION}

- Skeletally Class I and II subjects showed more gender variation than Class III subjects.

- Treatment of malocclusions should be based on gender differences rather than general treatment procedures, which will be useful in achieving successful orthodontic treatment results.

Ethics Committee Approval: Ethics committee approval was received for this study from the Ethics Committee of Gazi University (02.12.2016/14).

Informed Consent: Written informed consent was obtained from the patients who participated in this study.

Peer-review: Externally peer-reviewed.

Author Contributions: Concept - L.T., G.M.G.; Design - L.T., G.M.G.; Data Collection and/or Processing - G.M.G., F.D.U.; Analysis and/or Interpretation - L.T., G.M.G., F.D.U.; Literature Search - G.M.G., F.D.U.; Writing Manuscript - L.T., G.M.G., F.D.U.; Critical Review - L.T., G.M.G.

Conflict of Interest: The authors have no conflict of interest to declare.

Financial Disclosure: The authors declared that this study has received no financial support.

\section{REFERENCES}

1 Komazaki Y, Fujiwara T, Ogawa T, Sato M, Suzuki K, Yamagata Z, et al. Prevalence and gender comparison of malocclusion among Japanese adolescents: a population-based study. J World Fed Orthod 2012; 2: e67-e72. [CrossRef]

2. Kumar P, Londhe SM, Kotwal A, Mitra R. Prevalence of malocclusion and orthodontic treatment need in schoolchildren - An epidemiological study. Med J Armed Forces India 2013; 69: 369-74. [CrossRef]

3. Ishii N, Deguchi T, Hunt NP. Morphological differences in the craniofacial structure between Japanese and Caucasian girls with Class II Division 1 malocclusions. Eur J Orthod 2002; 24: 61-7. [CrossRef]
4. Ishii N, Deguchi T, Hunt NP. Craniofacial differences between Japanese and British Caucasian females with a skeletal Class III malocclusion. Eur J Orthod 2002; 24: 493-9. [CrossRef]

5. Celikoglu M, Akpinar S, Yavuz I. The pattern of malocclusion in a sample of orthodontic patients from Turkey. Med Oral Patol Oral Cir Bucal 2010; 15: e791-6. [CrossRef]

6. Shivakumar KM, Chandu GN, Subba Reddy VV, Shafiulla MD. Prevalence of malocclusion and orthodontic treatment needs among middle and high school children of Davangere city, India by using Dental Aesthetic Index. J Indian Soc Pedod Prev Dent 2009; 27: 211-8. [CrossRef]

7. Sidlauskas A, Lopatiene $K$. The prevalence of malocclusion among 7-15-year-old Lithuanian school children. Medicina (Kaunas) 2009; 45: 147-52. [CrossRef]

8. Kawashima S. Sex-dependent differences in the craniofacial morphology of children with a sleep-related breathing disorder. Oral Surg Oral Med Oral Pathol Oral Radiol Endod 2002; 94: 167-74. [CrossRef]

9. Baccetti T, Reyes BC, McNamara JA, Jr. Gender differences in Class III malocclusion. Angle Orthod 2005; 75: 510-20.

10. Avci S, Ergun T, Aydin E, Kansu L. Sex differences in adult craniofacial parameters. Surg Radiol Anat 2015; 37: 1069-78. [CrossRef]

11. Greulich WW, Pyle S. Radiographic Atlas of Skeletal Development of the Hand and Wrist. Am J Med Sci 1959:238-393. [CrossRef]

12. Darendeliler N, Taner L. Changes in the soft tissue profile after extraction orthodontic therapy. J Dent Child (Chic) 2006: 73: 164-9.

13. Alsulaimani F. Cephalometric Characteristics of Growing Children with Class I, II and III Malocclusions. Life Sci J 2014; 11: 145-51.

14. Basciftci FA, Uysal T, Buyukerkmen A. Craniofacial structure of Anatolian Turkish adults with normal occlusions and well-balanced faces. Am J Orthod Dentofacial Orthop 2004; 125: 366-72. [CrossRef]

15. Kilic N, Catal G, Oktay H. McNamara norms for Turkish adolescents with balanced faces and normal occlusion. Aust Orthod J 2010; 26: 33-7.

16. Türkdönmez CO, Taner L, Uzuner FD, Güngör K. Craniofacial Evaluation of Class I Turkish Adults: Bimler Analysis. Turk J Orthod 2014; 26 : 169-76. [CrossRef]

17. Lau JW, Hagg U. Cephalometric morphology of Chinese with Class II division 1 malocclusion. Br Dent J 1999;186:188-90. [CrossRef]

18. Sharma B, Bishnu P, Xin C. Comparative Cephalometric Analysis of Angle Class II Division 1 Malocclusion Between Nepalese and Chinese Subjects. Orthod J Nepal 2014; 4: 17-21. [CrossRef]

19. Rothstein T, Yoon-Tarlie C. Dental and facial skeletal characteristics and growth of males and females with class II, division 1 malocclusion between the ages of 10 and 14 (revisited)-part I: characteristics of size, form, and position. Am J Orthod Dentofacial Orthop 2000; 117: 320-32. [CrossRef]

20. Sharma B, Bishnu P, Xin C. Comparative Cephalometric Analysis of Angle Class II Division 1 Malocclusion between Chinese Male and Female Subjects. Orthod J Nepal 2015; 4: 21-3. [CrossRef] 